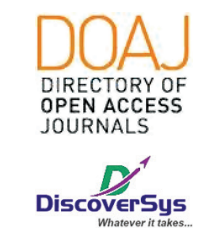

Published by DiscoverSys

\section{Impact of depression on the academic performance of international students in Udayana University}

\author{
Jacintha James, ${ }^{1 *}$ Anak Agung Sagung Sawitri, ${ }^{2}$ Luh Putu Ariastuti, ${ }^{2}$ Putu Aryani ${ }^{2}$
}

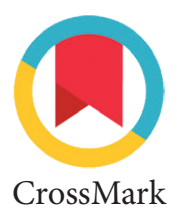

CrossMark

\title{
ABSTRACT
}

Background: Depression is a mental disorder that affects an individual's mood and emotion. Depression is very common among the students. In this study, the impact of depression, especially on the academic performance of students who are abroad, studies along with the risk factors of depression.

Aim: The study aims to know the relationship between depression and the academic performances of international students studying abroad.

Method: In this analytic study, a cross sectional method was being used. This method is being used to analyze the relationship between the factors that influence the academic performance and also to investigate the relationship between depression and academic performance of the students.

Result: As for the residence factor, the student who was lived alone performed better in academic. For the method of study factor, the student who conducts independent learning performs well in academic whereas for the factor back to Malaysia in a year, the students who go back to Malaysia less than or twice a year performs better in their academic. As for the family support factor, students who have good family support obtain good results in academic performance, but for factor family financial support, students with inadequate financial support obtain good results in their academic.
${ }^{1}$ Medical Science Study Program, Medical Faculty, Udayana University

${ }^{2}$ Department of Family and Preventive Medicine, Medical Faculty, Udayana University

*Correspondence to: Jacintha James, Medical Science Study Program, Medical Faculty, Udayana University jacinjames95@gmail.com

Received: 2018-04-07 Accepted: 2018-08-09 Published: 2019-08-01
Keywords: depression, academic performance, learning program

Cite This Article: James, J., Sawitri, A.A.S., Ariastuti, L.P., Aryani, P. 2019. Impact of depression on the academic performance of international students in Udayana University. Intisari Sains Medis 10(2): 180-183. D0I: 10.15562/ism.v10i2.213

\section{INTRODUCTION}

Depression is a serious mental disorder that gives lots of negative impact on an individual's life. ${ }^{1}$ Major Depressive Episode (MDE) has reported that 121 million people suffer around the world suffer from the depression, but today 350 million people suffer from depression according to the World Mental Health Survey. ${ }^{2}$ Some research has shown that major depressive disorder is twice as common in female $(12.0 \%)$ as in male $(6.6 \%){ }^{3}$ People suffering from depression means merely it affects their daily activity in life like eating, sleeping, working, relationship and how a person thinks about himself/ herself. Untreated depression will cause a person to feel fatigued, hopeless, lose concentration and also demotivated which will reduce their interest in the daily activities and work. ${ }^{1}$ Depression is a reaction to stress. The frequent and uncontrolled stress can lead to depression. Stress may affect a student's physical and psychological well-being if it is not adequately managed.

Regarding psychology, it is a mental state or emotional strain or tensed. ${ }^{4}$ Mostly, the student who studies abroad undergoes chronic stress that leads to depression which eventually influences their academic performances. Depression is ubiquitous among students. Research shows that forty billion students in the US suffer from depression. ${ }^{5}$ Recent analysis also has been demonstrated that the
Middle East and North African student have the highest rate of depression in the world according to researchers at Australia's University of Queensland. ${ }^{6}$ Impact of depression among students are decreasing in academic performances, make no friend, lose concentration, spend less time, lack of interest in activities and gain or loss weight due to change in appetite. Especially students who study abroad can easily get depressed.

Within the 2013 OECD annual education report, statistics have shown that there are already around 4.3 million tertiary level students studying outside their home country and more to increase every upcoming year. ${ }^{7}$ Moreover, research has shown that students of Asian-American have a higher rate of suicidal thoughts than 'White' college due to depression. ${ }^{8}$ This may happen due to the culture shock of being in a different country. Academic performances of students can be observed and measured as it is related to the depression's impact. ${ }^{9}$ This study is important to know the level of depression and the factors that direct distress in student studying abroad that can influence their academic

There are students from Malaysia studying in a few universities in Indonesia. Majority students from Malaysia take up medicine course in Indonesia. There is an article (April 29, 2015) performances. ${ }^{1}$ 
shows that around 1,300 international students are studying in Universitas Padjajaran (UNPAD), Bandung since the year 2000 and most of the students are from Malaysia. The article also states that higher education observer and Professor of the Bandung Institute of Technology, Satryo Soemantri Brodjonegoro says that the presence of international students is the recognition towards higher education in the international community. But then their admissions should be through the correct and tight selection process in order to give better impact on higher education intellectual dynamics. Therefore this shows that the performances of international students are still low. So far the academic achievements of Malaysian students in Indonesia are not good enough compared to the Indonesian students. Malaysian students could not adapt to their culture. Thus, their academic performance is low. But there are not many types of research carried out yet regarding the relationship between depression and academic achievement among them in Indonesia

Table 1 Characteristics of respondent

\begin{tabular}{|c|c|c|}
\hline Characteristics & Frequency & Percentage (\%) \\
\hline \multicolumn{3}{|l|}{ Residential } \\
\hline Living alone & 5 & 7.1 \\
\hline Living together with friends & 65 & 92.9 \\
\hline \multicolumn{3}{|l|}{ Method of studying } \\
\hline Sometimes study alone & 19 & 27.1 \\
\hline Always study alone & 51 & 72.9 \\
\hline \multicolumn{3}{|l|}{ Back to Malaysia in a year } \\
\hline More than twice & 26 & 37.1 \\
\hline Less than twice & 44 & 62.9 \\
\hline \multicolumn{3}{|l|}{ Language } \\
\hline English & 49 & 70.0 \\
\hline Bahasa Indonesia & 21 & 30.0 \\
\hline \multicolumn{3}{|l|}{ Family support } \\
\hline Bad & 36 & 51.4 \\
\hline Good & 34 & 48.6 \\
\hline \multicolumn{3}{|l|}{ Family financial support } \\
\hline Bad & 6 & 8.6 \\
\hline Good & 64 & 91.4 \\
\hline \multicolumn{3}{|l|}{ Depression } \\
\hline None & 28 & 40.0 \\
\hline Mild & 20 & 28.6 \\
\hline Moderate & 20 & 28.6 \\
\hline Severe & 2 & 2.8 \\
\hline \multicolumn{3}{|l|}{ Academic performance } \\
\hline Good $>3.0$ & 49 & 70.0 \\
\hline Poor $<3.0$ & 21 & 30.0 \\
\hline
\end{tabular}

yet to thoroughly proof these statement. ${ }^{10}$ Students which shows depressive symptoms has claimed low academic accomplishments. ${ }^{9}$ This relationship has not been further access yet. This depression cases should be diagnosed in student and must be treated.

\section{METHODS}

The study was an analytic cross-sectional study carried out at Udayana University, Denpasar Bali in early July 2017. The subject used in this survey is Malaysian students. The batches involved 70 students as from 2014, 2015 and 2016, respectively. Depression is well-known by using the diagnostic tool for depression, namely DSM-V by the American Psychiatric Association in the past seven days. According to T-scores interpretation, the students will be categorized into none depression and depression categories. Residential based on whether students are staying alone or together with friends currently. Method of studying is whether the students conduct a group study or independent learning. How often they go back is based on how many times the students go back to Malaysia in a year (more than twice, less than or twice). The first language is a person's native language that the students use commonly in campus (English or Bahasa Indonesia). Academic performance is measured based on students previous semester CGPA is based on their achievement in the prior examination of the semester. The score above 3.0 is good and below 3.0 is poor. Family support is known based on whether student's parents pressure them regarding on their studies that is whether the parents give pressure during examination (score $=$ yes (0), no (1)) and whether in daily conversation with the parents does the parents' consent about student studies (score $=$ yes $(1)$, no (0)). If the score is two then it is a good family support but if score less than 2 it is bad family support. Family financial status is known based on whether their monthly money if enough for their expenses (score $=$ yes (1), no (0)) and also whether the students get their pocket money on time (score $=$ yes $(1)$, no (0)). If the score is 2 then it is a good family financial support but if score less than 2 it is a bad family financial support.

\section{RESULTS}

This study should be explained based on the characteristics of the sample that is the residential, method of studying, how often they go back to Malaysia, language, family support, family financial support, diagnostic tool of depression that is DSM-V by the American Psychiatric Association in the past seven days and academic performance. 
Table 2 Relationship between impacts of depression on the academic performance

\begin{tabular}{|c|c|c|c|c|c|}
\hline \multirow[b]{2}{*}{ Academic Performance } & \multicolumn{2}{|c|}{ Good } & \multicolumn{2}{|c|}{ Poor } & \multirow[b]{2}{*}{$\mathbf{p}$} \\
\hline & $\mathbf{N}$ & $\%$ & $\mathbf{N}$ & $\%$ & \\
\hline \multicolumn{6}{|l|}{ Residence } \\
\hline Living alone & 4 & 80.0 & 1 & 20.0 & \\
\hline Living with friends & 45 & 69.2 & 20 & 30.8 & 1.000 \\
\hline \multicolumn{6}{|l|}{ Method of study } \\
\hline Group study & 12 & 63.2 & 7 & 36.8 & \\
\hline Independent learning & 37 & 72.5 & 14 & 27.5 & 0.446 \\
\hline \multicolumn{6}{|l|}{ Back to Malaysia in a year } \\
\hline$>2$ & 17 & 65.4 & 9 & 34.6 & \\
\hline$\leq 2$ & 32 & 72.7 & 12 & 27.3 & \\
\hline \multicolumn{6}{|l|}{ Language } \\
\hline English & 35 & 71.4 & 14 & 28.6 & \\
\hline Indonesia & 14 & 66.7 & 7 & 33.3 & 0.690 \\
\hline \multicolumn{6}{|l|}{ Family support } \\
\hline Good & 26 & 76.5 & 8 & 23.5 & \\
\hline $\mathrm{Bad}$ & 23 & 63.9 & 13 & 36.1 & 0.251 \\
\hline \multicolumn{6}{|l|}{ Family financial support } \\
\hline Good & 44 & 68.8 & 20 & 31.2 & \\
\hline $\mathrm{Bad}$ & 5 & 83.3 & 1 & 16.7 & 0.661 \\
\hline \multicolumn{6}{|l|}{ Depression } \\
\hline None depressed & 18 & 64.3 & 10 & 35.7 & \\
\hline Depressed & 31 & 73.8 & 11 & 26.2 & 0.394 \\
\hline
\end{tabular}

The majority of Malaysian students are living together with their friends (92.9\%). As from the results, the majority student prefers to study alone (72.9\%). Most students go back to Malaysia less than or twice in a year (62.9\%). Besides, most students use the English language as their native language in campus (70.0\%). They get bad family support (51.4\%). They got proper financial support from their family (91.4\%). Depression is divided into four categories that are none, mild, moderate and severe depression and majority students fall into none depression category (40.0\%). In addition, their performance were good in academic (70.0\%).

\section{Relationship between impacts of depression on the academic performance}

Table 2 showed the majority of students who lived alone performs better in academic (80.0\%) than the ones that live with friends. Based on the chi-square test, the expected value is less than 5 for more than $50 \%$ of cells. Therefore, the Fisher test will be used for the interpretation. The $\mathrm{p}$-value $=1.000$ which means it is more than $0.05(1.000>0.05)$. Therefore, Ho will be accepted, and $\mathrm{Ha}$ will be rejected. It showed that the risk factor residential does not affect the academic performances.

Based on the results above, majority of students who study alone obtain good results $(72.5 \%)$ than the one that conducts group study. The risk factor method of analyzing based on the chi-square test is the p-value $=0.446$. Therefore, Ho will be accepted, and $\mathrm{Ha}$ will be rejected. It showed that the risk factor method of studying does not affect the academic performances.

Most students who go back to Malaysia less than or twice in a year obtains a good result (72.7\%) than the ones that go back to Malaysia more than twice in a year. Based on the chi-square test the p-value $=0.517$ which Ho will be accepted, and Ha will be rejected. It showed that the risk factor going back to Malaysia in a year does not affect the academic performances. They who use the English language as their native language in campus have a good academic result $(71.4 \%)$ than the one that uses Indonesian language $(p=0.690)$. It showed that the risk factor language does not affect the academic performances.

Most students with good family support perform better in academic (76.5\%) than the ones with low-income family support $(\mathrm{p}=0.251)$. Furthermore, inadequate financial support component obtains good results (83.3\%) than the students with proper financial support from family $(\mathrm{p}=0.661)$. They who are depressed obtain good results in academic (73.8\%) than students who are not depressed $(\mathrm{p}=0.394)$. Those showed that depression did not have an impact on the academic performance of the Malaysian students.

\section{DISCUSSION}

The risk factors do not have impact on the academic performances of Malaysia students in Udayana University. Even though, researchers have shown that international students who study in U.S colleges face top 5 problems that were lack of English proficiency, inadequate financial resources, difficulties in social adjustment, problems in daily living and also loneliness or homesickness. ${ }^{11}$ Even though there was no significant association based on the study carried out in Udayana University, but the risk factors mentioned above do influence the academic performance of the students. There are students who perform well in their academic, but at the same time, the bad risk factors that are inadequate family support and lousy family support made the academic performance poorer. There is another research conducted in 2011 where the study was proven there is a negative relationship between depression and academic achievement of 
students which means the higher the depression among students, the lower their level of success. ${ }^{12}$ There was a study done in India university where the lower achievers in academic have a higher level of depression that more top scorers. ${ }^{13}$

The results show that the Malaysian students with depression performance better in their academic than students with none depression. Thus, that depression does not have impact on the academic achievements of the students in a negative way due to an insufficient amount of sample size obtain from Udayana University that was only 70 Malaysian students from batch 2014, 2015 and 2016 who participated in this study whereas more than 100 samples conducted the previous research. Besides, not all the students had severe depression some of them were in mild or moderate categories maybe that is why didn't influence their academic in a lousy way plus some of the students may use their depression as a motivator to excel well in academic.

\section{CONCLUSION}

Majority of the Malaysian students studying at Udayana University does not have depression and their academic performance are good. There is no relationship between the impacts of depression and academic achievement of Malaysia students in Udayana University.

\section{ACKNOWLEDGMENT}

First and foremost, the author would like to thank and give praise to God, for giving His blessings to complete this Elective Study Block. Finally, the authors would like to express the gratitude for all the people who have helped over the course of this paper, without them this paperwork would have been impossible to complete.

\section{REFERENCES}

1. Bin Yu, Xinguang Chen, Shiyue Li, Yang Liu, Angela J. Jacques-Tiura, Hong Yan. "Acculturative Stress and Influential Factors among International Students in China: A Structural.” Dynamic Perspective. PLoS ONE 2014; 9(4): 1-8. doi: 10.1371/journal.pone.0096322
2. WHO Department of Mental Health and Substance Abuse. "Depression: A Global Public Health Concern"; 2012. (viewed 16 January 2015). www.who.int/mental health/management/depression/who_paper_depression_ wfmh_2012.pdf

3. Oluwafunmilola, Omodona Oluwakemi. "Depression Among International Students" Ph.D. thesis, Central Ostrobothnia University Of Applied Science.

4. Vahedi Leila, Negar Taleschian Tabrizi, Kasra Kolahdouzan, Mohhamad Chavoshi, Babak Rad, Sara Soltani, Morteza Ghojazadeh. "Impact and Amount of Academic Selfefficacy and Stress on the Mental and Physical Well-Being of Students Competing in the 4th Olympiad of Iranian Universities of Medical Sciences". 2014; 3(2): 99-104.

5. Kerr Michael. Depression and College students; 2012. (viewed 16 January 2016). www.heathline.com

6. Dewey Caitlin. "A stunning map of depression rates around the world," Wonkblog, weblog post; November 7, 2013. Accessed on: 16 January 2015, https://www.washingtonpost.com.

7. Ching, Gregory S., Chao, Pei-Ching, Lien, Wei-Chih. "Acculturative hassles and strategies: Relationship between study abroad related depression, anxiety, and stress". 2014; 3(5): 3-25

8. Jun-Youb Lee. Crushed by Parental and Societal Pressure, Asian American Students are resorting to suicide; 2014. (viewed 16 January 2015) www.alternet.org

9. Hysenbegasi Alketa, Steven L. Hass, Clayton R. Rowland. "The Impact of Depression on the Academic Productivity of University Students". The Journal of Mental Health Policy and Economics J Ment Health Policy Econ. 2005; 8: 145-51.

10. ACDP INDONESIA (Education Sector Analytical and Capacity Development Partnership). Education News Monitoring Service: Foreign Students Lively; 2015. (viewed 16 January 2015) https://acdpindonesia.wordpress.com

11. Delphine N. Banjong. "International Students' Enhanced Academic Performance: Effects of Campus Resources". 2015; 5: 132-142

12. Lama M. Al-Qaisy. "The relation of depression and anxiety in academic achievement among group of university students", 2011; 3 (5): 96-100Hamza M. Abdulghani, Abdulaziz A. AlKanhal, Ebrahim S. Mahmoud, Gominda G. Ponnamperuma, and Eiad A. Alfaris. "Stress and Its Effects on Medical Students: A Cross-sectional Study at a College of Medicine in Saudi Arabia”. 2011; 29: 516-22.

13. Sindhu P. "Impact of Depression on Academic Achievement among Engineering Students". 2012; 4(82): 49-54

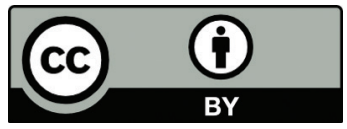

This work is licensed under a Creative Commons Attribution 